\title{
Development Method of Intellectual Capital Management in Current Scenario of Business Management
}

\author{
Budi Wahyu Mahardhika, Aryo Prakoso, Muchtar Anshary Hamid Labetubun, Phong Thanh \\ Nguyen, K. Shankar
}

\begin{abstract}
Sum of the knowledge in an organization can be considered as intellectual capital. This knowledge exists at different levels, outside or within the organization implies that knowledge. Many processes and products are having intangible nature, in corporate balance sheets to increase the intellectual capital management they enhance the value. The intellectual capital known as the exertion or work that a part put into the association as intangible resources. These assets incorporate information assets like copyright, licenses, trademarks and other human's thoughts and analyses. So we can say that intellectual capital is the gathering of all assets like social capital, basic and human, these are the assets that set the authoritative focused worth
\end{abstract}

Keywords: organization, intellectual capital, knowledge, intangible resources

\section{INTRODUCTION}

In 2012 Okafor denied that each business requires assets as physical, monetary and intangible resources. Absence of, or lacking assets of any sort may put a firm in a helpless position, and may undermine its prosperity. In this time of national just as worldwide money related emergency, the investigation of the significance of intangible assets has pulled in much consideration in the business the executives writing, since intellectual capital which is a part of impalpable resource has that applying impact of increasing the value of a firm and with its social capacity can encourage the securing of different assets which advance the survival and productivity of a firm.

Intellectual Capital is characterized as all learning inside an association which can possibly make esteem when applied in accordance with the mission, vision and objectives of the association. It alludes to the impalpable capital (for example other than monetary capital) possessed by organizations:

Human Capital: For future growth and current operation the value that people bring is known as human capital.

Revised Version Manuscript Received on 16 September, 2019.

* Correspondence Author

Budi Wahyu Mahardhika, Universitas Muhammadiyah Surabaya, Indonesia. E-mail: budi.wahyu.m@fe.um-surabaya.ac.id

Aryo Prakoso, universitas Jember, Indonesia

Muchtar Anshary Hamid Labetubun, Universitas Pattimura, Ambon, Indonesia.

Phong Thanh Nguyen*, Department of Project Management, Ho Chi Minh City Open University, Vietnam. E-mail: phong.nt@ou.edu.vn

K. Shankar, Department of Computer Applications, Alagappa University, India. E-mail: shankarcrypto@gmail.com
Structural Capital: structural capital also known as organizational capital. This is considering as a supporting infrastructure that support human and company capital.

Network Capital: It is also known as supplier or customer capital. For future growth many factors starts relationship between loyalty of suppliers, customers and other business.

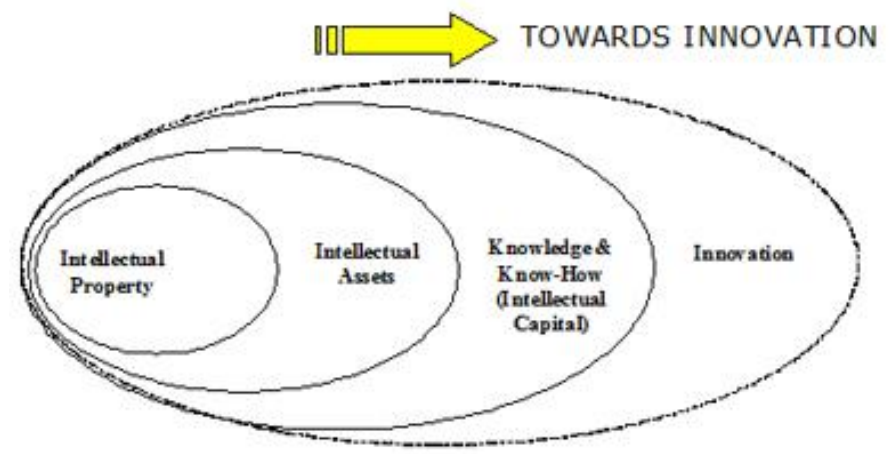

Figure 1: Intellectual capital towards innovation

Intellectual Capital: For creating the value knowledge that is used

Intellectual Assets: For creating the value codification of knowledge

Intellectual Property: Intellectual capital legally protected

\section{The Concept of InTellectual Capital}

In the expressions of Thomas Stewart" intellectual capital is something that can't be contacted, despite the fact that it gradually makes you rich". In 2005 Jacob Ben-Simchon depict intellectual capital as an abridgment of non-unmistakable or non-physical resources and assets of an association, just as its practices, licenses and the understood learning of its individuals and their system of accomplices and contracts. Characterizes it as 'bundled helpful information' in 1997 by Stewart, in 2000 Sullivan as 'learning that can be changed over into benefit', in 1997 Roos et al as the 'whole of learning' of its individuals and functional interpretation of this information into brands, trademarks and procedures. 


\section{FACTORS OF INTELlECTUAL CAPITAL MANAGEMENT PROCESS}

1. Improving the worth creaton, extraction and discharge cycles for new and existing activities

2. Breaking down existing venture learning, refreshing it and recording it beyond what many would consider possible and making it sharable inside the undertaking so as to more readily satisfy the strategies. This turns into the venture's 'structural capital';

3. Distinguishing potential wellsprings of income that could be extricated from existing basic capital and creating showcasing plans for them;

4. Making the atmosphere in which information laborers can best perform;

5. Surveying dangers associated with securing the undertaking's scholarly resources (or structural capital) and utilizing a powerful protected innovation methodology to limit business chance.

\section{COMPONENTS OF INTELLECTUAL CAPITAL}

The components of Intellectual Capital are described below:

\section{Human capital}

In 2000 Bontis et al. defined that the stock of individual knowledge of an organization introduced by human capital. And this knowledge is presented by employee of that organization. In 1999 Bontis represented that as the source of innovation and strategic renewal the concept of human capital is very important, may be its in any type. In 2011 Shaari et al., in 1997 Roos \& Roos dicted that in an organization human capital is the major sourse of intellectual capital.
In 2001 Tai-Ning et al. and Shaari et al., in 1997 Malone and Edvinson defined that on the basis of connection between cutomer and enterprise the customer capital is also a main element of intellectual capital. In 2001 Roos et al., proposed that for enjoy competitive advantage having good connection with emplyees is very important aspect.

\section{Structural Capital}

In 2013 Khalique et al. defined that concept of Structural capital as a glue for organization. In 2000 Bontis et al., and in $2005 \mathrm{Wu} \&$ Tsai introduced that all non-human stores of knowledge consists in Structural capital. These non-human stores of knowledge are like policies and routines, data-bases, organizational charts, process manuals, strategies and data-bases.

\section{Social Capital}

According to Khalique et al. in 2011 and Bueno et al. in 2004 other significant component of intellectual capital is Social capital. The social capital related with performances of firm. In 2003 Ireland et al. defined that for achieving sustainable competitive advantages in organizations Social capital is the most significant sources

\section{Technological Capital}

In 2011 Khalique et al. defied that in knowledge-based economy a critical component is Technological capital.

\section{Spiritual Capital}

In 2005 Ismail introduced that in intellectual capital Spiritual capital is also act as a vital component. In 2003 Hefinar and Berger defined that knowledge, influence, power and spirit are the knowledge of the Spiritual capital. These are derived from religion.

\section{Customer Capital}

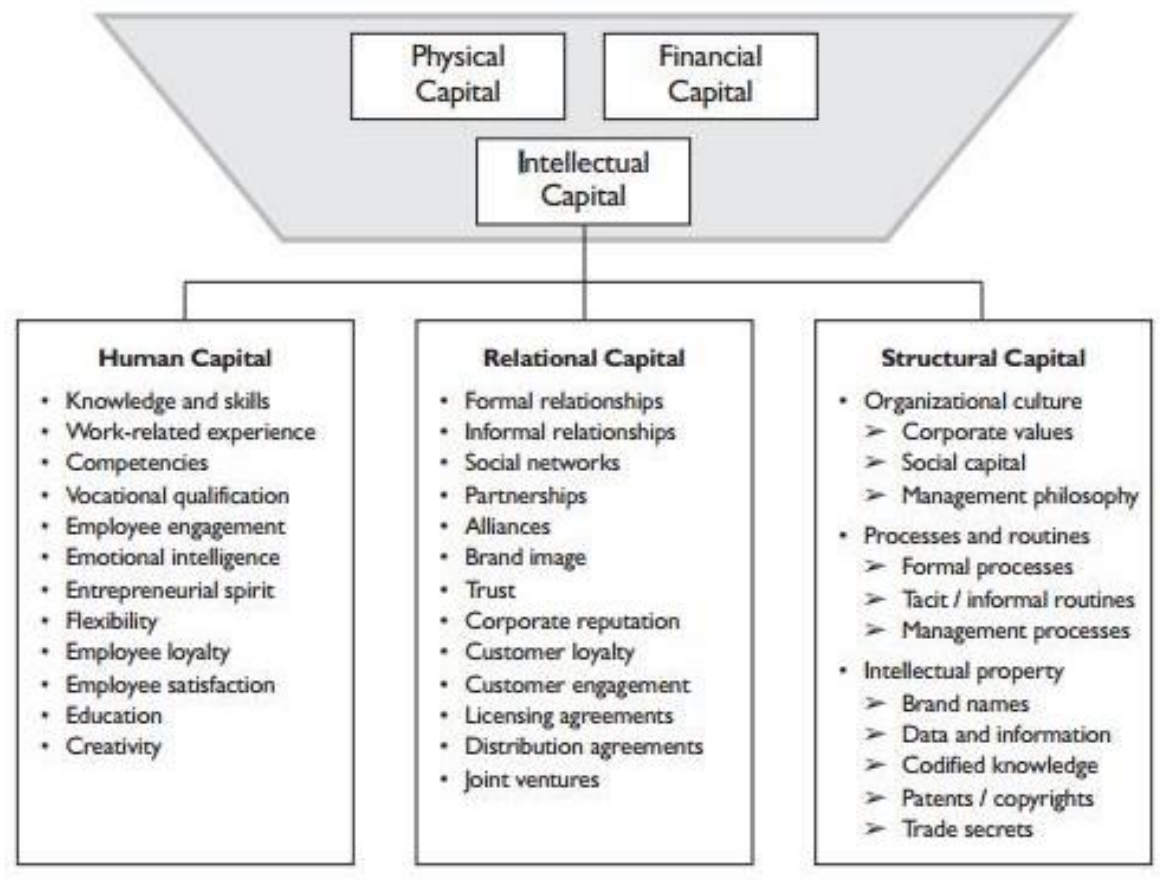

Figure 2: Intellectual Capital managemnet Components 


\section{INTELLECTUAL CAPITAL MANAGEMENT MODEL}

\section{The model of Intellectual capital management include following steps:}

1. Identify intellectual capital - is a stage in that intangible assets are resolved and depicted that may affect hierarchical aggressiveness. They can be recognized at the hierarchical level, division level or at the individual level. This progression is executed by an individual gifted in the craftsmanship called inner examiner.

2. Intellectual capital Measurement- this stage is begun subsequent to existing immaterial assets inside the organization, office or individual level have been recognized and are viewed as crucial to get upper hand.

3. Action plan - This progression includes discovering approaches to improve the outcomes acquired in the progression of estimating scholarly capital. Beginning the activity plan is a proposition procedure and deciding the right choice system including the execution of restorative activities and diminishes the dangers related scholarly capital. The viability of this progression adds to accomplishing the association's destinations and boosts the worth made

4. Intellectual capital Monitoring - when the activity plan has been executed, the point is accomplished if the objectives set by the supervisor. The reason for this progression is to keep up the worth made.

5. Report - in this progression, the estimation scholarly capital outcomes are displayed to the administrator (complete score), making a diagram of the worth made for the association of these immaterial resources.

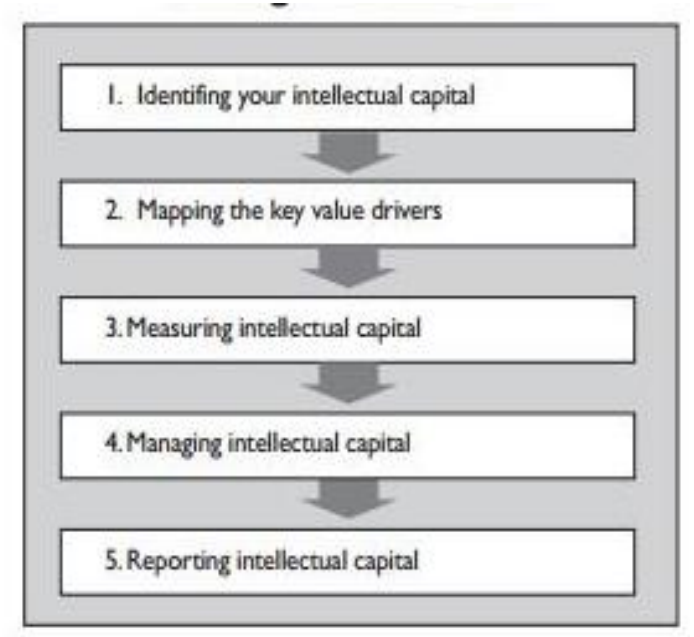

Figure 3: Intellectual capital management model

\section{CONClusion}

The learning of an association or an organization that exists on inside the association or outside the association is the piece of Intellectual capital. Blend of information is alludes to as Intellectual capital. The Intellectual capital known as the effort or work that a section put into the relationship as insignificant resources. These benefits fuse data resources like copyright, licenses, trademarks and other human's musings and assessments. So we can say that insightful capital is the get-together of all benefits like social capital, essential and human [1], these are the advantages that set the definitive forceful worth. It is the estimation of human capital, discerning capital and basic capital that identify with its relationship.

\section{REFERENCES}

1. Jacob Ben-Simchon (2005). 'Reporting of intellectual capital in research intensive SME's final Dissertation', The University of Inholland.

2. Stewart, Thomas A. (1997): "Intellectual capital: the new wealth of organizations", Doubleday New York, NY, USA.

3. Sullivan P H (2000). Value-driven Intellectual Capital: How to convert Intangible Corporate Assets into Market Value, Toronto, Canada: John Wiley and Sons.

4. Roos, Johan et al (1997): Intellectual Capital: Navigating the new business landscape.Macmillan Press Ltd, London.

5. Chienwattanasook, K., Wattanapongphasuk, W., Prianto, A., \& Jermsittiparsert, K. 2019. "Corporate Entrepreneurship and Business Performance of Logistic Companies in Indonesia." Industrial Engineering \& Management Systems 18 (3): 538-547.

6. Dawabsheh, M., Hussein, A., \& Jermsittiparsert, K. 2019. "The Triangular Relationship between TQM, Organizational Excellence and Organizational Performance: A Case of Arab American University Palestine." Management Science Letters 9 (6): 921-932.

7. Jermsittiparsert, K., Siam, M., Issa, M., Ahmed, U., \& Pahi, M. 2019. "Do Consumers Expect Companies to Be Socially Responsible? The Impact of Corporate Social Responsibility on Buying Behavior." Uncertain Supply Chain Management 7 (4): 741-752.

8. Syazali, M., Putra, F., Rinaldi, A., Utami, L., Widayanti, Umam, R., \& Jermsittiparsert, K. 2019. "Partial Correlation Analysis Using Multiple Linear Regression: Impact on Business Environment of Digital Marketing Interest in the Era of Industrial Revolution 4.0.' Management Science Letters 9 (11): 1875-1886.

9. Sae-Lim, P. \& Jermsittiparsert, K. 2019. "Is the Fourth Industrial Revolution a Panacea? Risks toward the Fourth Industrial Revolution Evidence in the Thai Economy." International Journal of Innovation, Creativity and Change 5 (2): 732-752.

10. Chatchawanchanchanakij, P., Arpornpisal, C., \& Jermsittiparsert, K. 2019. "The Role of Corporate Governance in Creating a Capable Supply Chain: A Case of Indonesian Tin Industry." International Journal of Supply Chain Management 8 (3): 854-864.

11. Hartinah, S., Suharso, P., Umam, R., Syazali, M., Lestari, B., Roslina, R., \& Jermsittiparsert, K. 2020. "Teacher's Performance Management: The Role of Principal's Leadership, Work Environment and Motivation in Tegal City, Indonesia." Management Science Letters 10 (1): 235-246.

12. Haseeb, M., Hussain, H., Slusarczyk, B., \& Jermsittiparsert, K. 2019. "Industry 4.0: A Solution towards Technology Challenges of Sustainable Business Performance." Social Sciences 8 (5): 184.

13. Haseeb, M., Hussain, H., Kot, S., Androniceanu, A., \& Jermsittiparsert, K. 2019. "Role of Social and Technological Challenges in Achieving a Sustainable Competitive Advantage and Sustainable Business Performance.” Sustainability 11 (14): 3811.

14. Haseeb, M., Kot, S., Hussain, H., \& Jermsittiparsert, K. 2019. "Impact of Economic Growth, Environmental Pollution, and Energy Consumption on Health Expenditure and R and D Expenditure of ASEAN Countries." Energies 12 (19): 3598.

15. Huda, S., Tsani, I., Syazali, M., Umam, R., \& Jermsittiparsert, K. 2020. "The Management of Educational System Using Three Law Auguste Comte: A Case of Islamic Schools.” Management Science Letters 10 (3) (In press), DOI: 10.5267/j.msl.2019.9.018.

16. Usak, M., Kubiatko, M., Shabbir, M., Dudnik, O., Jermsittiparsert, K., \& Rajabion, L. 2019. "Health Care Service Delivery Based on the Internet of Things: A Systematic and Comprehensive Study." International Journal of Communication Systems 32 (14): e4179.

17. Jermsittiparsert, K., Ambarita, D., Mihardjo, L., \& Ghani, E. 2019. "Risk-Return through Financial Ratios as Determinants of Stock Price: A Study from ASEAN Region." Journal of Security and Sustainability Issues 9 (1): 199-210.

18. Thabhiranrak, T. \& Jermsittiparsert, K. 2019. "Towards Sustainable Functioning of Organization: Women Empowernment and Corporate Management Culture.” Journal of Security and Sustainability Issues 9 (1): $321-332$. 
19. Chienwattanasook, K. \& Jermsittiparsert, K. 2019. "Impact of Entrepreneur Education on Entrepreneurial Self-Employment: A Case Study from Thailand." Polish Journal of Management Studies 19 (1): 106-116.

20. Jermsittiparsert, K., Sutduean, J., Sriyakul, T., \& Khumboon, R. 2019. "The Role of Customer Responsiveness in Improving the External Performance of an Agile Supply Chain." Polish Journal of Management Studies 19 (2): 206-217.

21. Jermsittiparsert, K., Sutduean, J., \& Sriyakul, T. 2019. "Effect of Service Innovation and Market Intelligence on Supply Chain Performance in Indonesian Fishing Industry." Industrial Engineering \& Management Systems 18 (3): 408-417.

22. Jermsittiparsert, K., Namdej, P., \& Somjai, S. 2019. "Green Supply Chain Practices and Sustainable Performance: Moderating Role of Total Quality Management Practices in Electronic Industry of Thailand." International Journal of Supply Chain Management 8 (3) 33-46.

23. Somjai, S. \& Jermsittiparsert, K. 2019. "The Trade-off between Cost and Environmental Performance in the Presence of Sustainable Supply Chain." International Journal of Supply Chain Management 8 (4): 237-247.

24. Jermsittiparsert, K. \& Sawasdee, A. 2012. "Formal Education for Non-Thai or Undocumented Person in Thailand amidst the Challenge of Nationalism and Transnationalism: A Case Study of Wat Sirimongkhol School, Samut Sakhon Province.” Kasetsart Journal Social Sciences 33 (2): 203-213.

25. Bontis, N., Keow, W. C. C., \& Richardson, S. (2000). Intellectual capital and business performance in Malaysian industries. Journal of Intellectual Capital, 1(1), 85-100.

26. Bontis, N. (1999). Managing organizational knowledge by diagnosing intellectual capital:

27. framing and advancing the state of the field. International Journal of Technology Management, 18(5/6/7/8), 433-463.

28. Shaari, J. A. N., Khalique, M., \& Isa, A. H. B. M. (2011). Ranking of public and domestic private sector commercial banks in Pakistan on the basis of intellectual capital performance. Khadim Ali Shah Bukhari Institute of Technology Business Journal, 4, 61-68.

29. Roos, G., \& Roos, J. (1997). Measuring your company's intellectual capital performance. Long range planning, 30(3), 413-426.

30. Tai-Ning, Y., Hsiao-Chen, C., Shou-Yen, L., \& Chiao-Lun, T. (2011). Knowledge creation and intellectual capital on securities investment services. African Journal of Business and Management, 5(3), 924-933.

31. Acquaah, M. (2012). Social networking relationships, firms-specific managerial experience and firm performance in a transition economy: a comparative analysis of family owned and nonfamily firms. Research notes and commentaries. Strategic Management Journal, 33, 1215-1228.

32. Roos, G., Bainbridge, A., \& Jackobsen, K. (2001). Intellectual capital analysis as a strategic tool. Strategy \& Leadership, 29(4), 21-26.

33. Khalique, M., Shaari, J. A. N. b., Isa, A. H. M., \& Samad, N. B. (2013). Impact of Intellectual Capital on the Organizational Performance of Islamic Banking Sector in Malaysia. Asian Journal of Finance \& Accounting, 5(2), 75-83.

34. Wu, W. Y., \& Tsai, H. J. (2005). Impact of social capital and business orientation mode on intellectual capital and knowledge management. International Journal of Technology Management, 30(1/2), 147-171.

35. Bueno, E. Salmador, M. P., \& Rodriguez, O. (2004). The role of social capital in today's economy; empirical evidence and proposal of new model of intellectual capital. Journal of Intellectual Capital, 5(4), 556-574.

36. Ireland, R. D., Hitt, M. A., \& Sirmon, D. G. (2003). A model of strategic entrepreneurship: the construct and its dimensions. Journal of Management, 29(6), 963-989

37. Benbasat I. \& Zmud R.W. 1999 'Empirical Research in Information Systems: The Practice of Relevance' MIS Quarterly, Vol. 23, No. 1, pp. 3-16. 